\title{
SCIENCE, KNOWLEDGE AND UNDERSTANDING: WITTGENSTEIN BETWEEN PHENOMENOLOGY AND POSITIVISM ${ }^{1}$
}

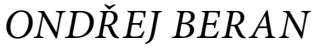

$\mathrm{PhD}$ in Philosophy.

University of Pardubice, Faculty of Arts and Philosophy, Department of Philosophy. 53210 Pardubice, Czech Republic.

E-mail: ondrej.beran@upce.cz

The paper explores some philosophical consequences of the phenomenological criticisms addressed (indirectly) to logical positivism. It introduces arguments by Husserl and Patočka concerning the duality inherent to the notion of world, as suggested by modern scientism: the real world is alleged to be different from, and hidden behind, the everyday appearance (perception) of the world and things within it. Carnap's project of reconstructing (scientific) knowledge in reductionist terms of psychological-atomic sense-data-and, ultimately, physical objects distinguishes him from Husserl: for the latter, meaningful experience originates in primitive encounters with meaningful things. Both, however, share a certain preoccupation with reductionist analyses of scientific rigour, while this tendency has been abandoned in Wittgenstein's works. His expanded notion of verification betrays motivations of a phenomenological kind. He tries to show that the relationship between simpler and more complex contents of knowledge is a relationship between contents playing different, but interlinked, roles within our practices of understanding and making ourselves intelligible. Understanding other people and the events in their lives in terms of a soul (and what happens to it) is not a marginal, eccentric, or derivative case: it is the central, primitive form of this understanding. Wittgenstein's working with the notion of 'soul' parallels Husserl's analyses from Ideas II.

Key words: Phenomenology, logical positivism, knowledge, natural world, verification, soul, Wittgenstein.

1 The publication was supported within the project of Operational Programme Research, Development and Education (OP VVV/OP RDE), 'Centre for Ethics as Study in Human Value,' registration No. CZ.02.1.01/0.0 /0.0/15_003/0000425, co-financed by the European Regional Development Fund and the state budget of the Czech Republic. I would also like to thank to the anonymous reviewers for their suggestions.

(C) ONDǨEJ BERAN, 2019 


\section{НАУКА, ЗНАНИЕ И ПОНИМАНИЕ: ВИТГЕНШТЕЙН МЕЖДУ ФЕНОМЕНОЛОГИЕЙ И ПОЗИТИВИЗМОМ 2}

\section{ОНДРЖЕЙ БЕРАН}

Доктор философии.

Университет Пардубице, факультет искусств и философии, департамент философии.

53210 Пардубице, Чешская Республика.

E-mail: ondrej.beran@upce.cz

В статье исследуется ряд философских следствий (косвенной) критики логического позитивизма о стороны феноменологии. Приводятся аргументы Гуссерля и Паточки относительно дуализма, внутренне присущего понятию мира в современном сциентизме: предполагается, что реальный мир отличен от повседневной видимости (восприятия) мира и внутримировых вещей и укрыт за нею. Карнапов проект редукционистской реконструкции научного знания сквозь призму психологических атомарных чувственных данных и, в конечном счете, физических объектов, отличается от Гуссерлева, для которого осмысленный опыт возникает в изначальном столкновении с осмысленными вещами. Однако оба они разделяют определенный интерес к редукционистскому анализу с научной строгостью, тогда как в трудах Витгенштейна это стремление оставлено. Расширенное представление Витгенштейна о верификации содержит в себе мотивацию феноменологического характера. Он пытается показать, что отношение между более простым и более сложным содержанием знания есть отношение между элементами, играющими различные, но взаимосвязанные роли в наших практиках понимания и взаимопонимания. Понимание других людей и событий в их жизни в категориях души (и того, что с ней происходит) не является маргинальным, эксцентричным и производным. Это центральная, изначальная форма понимания. Трактовка Витгенштейном понятия «души» содержит в себе параллель с Гусерлевым анализом в Идеях II.

Ключевые слова: Феноменология, логический позитивизм, знание, естественный мир, верификация, душа, Витгенштейн.

\section{INTRODUCTION}

What is knowledge? When do we say that we know something and when can we say it? Can knowledge be located to a particular subset or subspecies of our experiential or mental contents (perhaps), such that can be reconstructed clearly and undisputedly using a warranted method of philosophical analysis? These are far-reaching questions; I will only deal with the shape they took in the context of

\footnotetext{
2 Публикация подготовлена в рамках проекта оперативной программы исследования, разработки и образования (OP VVV/OP RDE) «Центр этики как исследование человеческой ценности», регистрационный номер CZ.02.1.01/0.0/0.0/15_003/0000425, софинансируется Европейским фондом регионального развития и государственным бюджетом Чешской Республики. Я также хотел бы поблагодарить анонимных рецензентов за их предложения.
} 
the contrasting attitudes to these questions adopted by two influential philosophical traditions of the interwar Europe: phenomenology and positivist scientism.

Given both traditions' interest in perception and experience, they both addressed these questions in akin terms, though their answers pointed to different directions, in some respects contradictory. More often than not, however, phenomenology and positivism didn't communicate with each other directly. Even when they were issuing criticisms aiming, also, at each other-criticisms of narrowminded scientism on the one hand, of irrationality and a lack of scientific rigour on the other hand-, these arguments, powerful and inspirational until today, only partly captured the real position of the other side.

There is a body of historical research tracing the links of acquaintance between Husserlian phenomenology and logical positivism. My ambition, however, is rather to focus on what light some vital points of phenomenological criticism of scientism, and of some more loosely related philosophical conceptions, throw on the nature of knowledge-the different senses in which we can know thingsand our understanding of the world. My overall aim is to move to the particular sense in which Wittgenstein's-and Wittgensteinian-philosophy represents a way of surpassing the limitations of what is (not always justly) considered to be the positivist conception of knowledge. Though Wittgenstein himself does not stand in the phenomenological tradition, his approach—somewhat paradoxically-yielded a prime example of philosophy driven by motivations of the kind of phenomenology's anti-scientism ethos.

In the first section, I attempt to overview the motivation the phenomenological criticisms of scientism as issued by the later Husserl and the early Patocka. In the second section, I introduce important points of Carnap's proposal of analysing knowledge, with an emphasis on what is especially relevant from the phenomenological viewpoint. I go into more detail to show that the core of the disagreement between phenomenology and scientifically-minded philosophy (as famously, though perhaps not quite justly, represented by Carnap) has to do with the different nature and purpose of the reductionist analyses performed by Husserl and Carnap. In the third section, I suggest what alternative to this irreconcilable disagreement is offered by Wittgenstein's non-scientific conception of verification and the way it can be elaborated in accordance with the new directions opened by his later philosophy of language. I try to point out the sense in which this elaboration aligns with phenomenology more naturally than it would with the Vienna Circle's positivism. In the fourth section, I discuss the role that examples (concepts) like soul play here. 
Husserl's critique of scientism is clearest in his late writings, especially in the opening part of his Crisis of European Sciences and Transcendental Phenomenology (Husserl, 1970). Its $\$ \$ 1-7$ are a reworked version of his successful Prague lectures on "The Crisis of European Science and Psychology". Although the greater part of the book organically develops Husserl's lifelong ideas of the phenomenological method, its opening places these philosophical tools into the rather unique framework of a broader critique of the decline of the intellectual and cultural atmosphere of Europe.

The Prague setting is not irrelevant. It was the founding figure of the Czech phenomenology and notable Husserl's pupil Jan Patočka who was instrumental in organising the invited lectures. Patočka's work from the same time also most directly (among his phenomenological contemporaries) pursues the motive of 'the crisis of

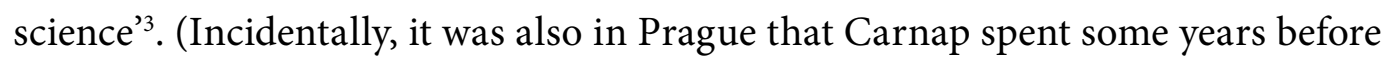
he fled to the U.S., leaving, however, unlike Husserl, no flourishing school behind.)

Husserl's critical preoccupation with modern scientism stems from its pervasive influence to the philosophy of his time. For him, the inspiration that philosophy took from successful and fruitful modern science led to a continuous misdirection of the European philosophical tradition. Husserl did not directly address his contemporaries and their enterprises through logical empiricism. He saw Galileo as the determining figure of this development, encouraged by his naturalistic view of the world as a book written in the language of mathematics, i.e. whoever wishes to indeed know anything about our world, must be proficient in its language.

The scientism that Husserl was targeting was, however, his contemporary afterglow of Galileo's intuitions; in this sense, his criticisms could have concerned also the agenda of the Vienna Circle, as propounded in its 1929 manifesto. Much of his criticism is congenial to the manner in which the work of Vienna Circle is often understood as representative of scientism and, as such, dated. While the work of Carnap and other like-minded philosophers could have acted as a natural stimulus for Husserl's critique, it is debatable to what extent this is an appropriate account of Carnap's work. The phenomenological attacks concern (with some reservations) Carnap's early work, such as the Aufbau, but probably don't reach much beyond.

More can be found in Moural (2013). 
(I will try to explore this later). The critique is, however, interesting in itself, as an expression of the spirit that was characteristic of phenomenology in the laterHusserlian line, and that has not lost its appeal to this day.

The core of Husserl's Prague lectures goes against the direction attributed commonly to logical empiricism. Husserl elaborates on his earlier phenomenological analysis of the world, arguing that modern science had lost its capacity and, more alarmingly, ambition to say anything about the world of human lives (Lebenswelt), or, to simply talk about the world in such terms in which it is actually 'lived.' This withdrawal of science from people's lives was the reason why people, in search of a meaningful statement about the world that would appeal to them as being relevant to personal experience (but profound and structured), reverted to irrationality and superstition: "the rationality of lazy reason." Modern science, in Husserl's eyes, lacked phenomenological focus, i.e. the goodwill to express the true nature of the objects it talked about. This conscious resignation betrayed a lack of self-reflection on science's part. Instead of respecting the primitive character of everyday experience of meaningful 'things,' it thus discovered, as the true nature of things and processes in the world, their geometrical and mathematised characteristics, e.g. extension in three-dimensional space, laws of physics, etc ${ }^{4}$.

The point of phenomenological analyses explored by Husserl for decades is to show that such characteristics as the extension in the three-dimensional external world are supplemented to the encountered things and beings. This is an additional thesis that can be dissected from their true meaning under the phenomenological scalpel. What we see within the world are things, which we encounter as things (rather than gradually synthesised aspects of things) and keep them in our consciousness as being continuous in time: things such as chairs that appear to us as relevant in a particular way. Their material, external three-dimensionality plays no substantial role in this experiential encounter and must be, therefore, separated as non-constitutive. The world is not of a spatial nature; it is an ultimate horizon, against which we are able to have such encounters. The scientific neglect of the world of meaningful things we experience and the zealous search 'beneath' this 'surface' is the reason why people have ceased to expect science to talk about the world in which they live. The productivity of science in cumulating empirical data remains uncontested

4 Stone (2010) argues that the early Carnap's conception of space as, ultimately, 'the space of perception,' was probably influenced by Husserl, who also saw the Anschauungsraum as the intuitive space, as opposed to the 'substructed' three-dimensional space described by mathematics. 
by most people. They have only learned to compartmentalise their expectations. It is proper to respect scientific discoveries of electrons and quarks, not least because they can be relevant for engineering solutions in the field of constructing bridges or spaceships. On the other hand, these discoveries gradually became irrelevant to the point and direction of one's life, as a European, a citizen, a Christian, a parent, and so on.

This inherent trouble with the meaning of the world is made more explicit in Patočka's early work. A year after Husserl's visit to Prague, he published The Natural World as a Philosophical Problem. There, Patočka identifies modern science as the source of the estrangement within our very notion of the world. The world we live in is, originally, a horizon of sense (of meaningful things), within which we orient ourselves as free and creative beings, capable of reflecting the world as a whole. On the other hand, science suggests that the real world has a different character: it is the object of our cognition (scientific knowledge), rather than of our perception, situation and everyday experience. The true nature of the world (the laws governing it) is not directly perceived: it is hidden from our perceptive capacities and only science can uncover it. Also, the nature of the world, as science finds it, is deterministic; the laws of nature leave no space for actions understood as performed by free, creative beings. As a result, we are confronted with two different, discontinuous worlds: their concepts are incompatible and in competition for primacy. However, philosophy should analyse the world as the world we live in, and not try to replace it by a 'realer' one (Patočka, 1992, \$\$1.1, 1.2.).

Patočka is somewhat less interested than Husserl in the constitution of our world of things: his attention is strongly directed towards the question of the nature of human engagement within the world. Therefore, there is an emphasis on our capacity to conceive of the world as a meaningful whole and to act within it as such that is a space for free, creative agency. The world, along with its meaning, is (at least partially) constituted by human work, including also theoretical reflections and free decisions (uniquely human capacities). In his later work, he investigates the human existence within the world as a complex of three existential 'movements,' by which we i) place ourselves in the world, ii) relate to the things of the world as to certain extensions of our physical possibilities and iii) transcend ourselves towards the world as a whole. (A metaphysical, Aristotelian notion of movement.) Only through these movements of who we as existing humans are can things of this world be revealed for what they are (Patočka, 1995, 104 ff.). The very project of science (scientific knowledge) cannot be understood unless as performed by beings 
who relate to themselves and are engaged with the world through these movements. The concepts science employs (sense-data, electrons, etc.) should not be conceived otherwise than as certain elements of human existential movements towards and within the world.

Husserl's optimism in challenging scientism stemmed partially from his long-standing ambition to provide a scientific philosophy in its own right, a phenomenological science that would replace, within philosophy, the hitherto regnant paradigm of natural science. He wants to protect the conception of science from being reduced to objective science in the naturalistic sense (Husserl, 1970, \$34a), conceding eventually, however, that "this dream is over" (Husserl, 1970, 389). This tension inherent to his later philosophy's explorations of the sense in which (if at all) it could advocate for-and produce an example of-philosophy as science leaves Husserl's project halfway. This problem was, however, not so much connected to the philosophy's lack of universality, but rather to some differences between the points of the enterprises of philosophy and objective science. Science concerns procedures and tools suitable for the efficient production of factual discoveries. These procedures can be applied by anyone (but if nobody applies them, it does not change anything about their efficiency). Philosophy, on the other hand, seems to provide a light in which the important structural points of one's experience of the world are highlighted. The person engaged is therefore needed, since what is highlighted is inherently tied to her situated experience. It makes no sense to say that philosophy discovers something using procedures applicable independently of the person concerned; that there is a concerned somebody is an intrinsic part of the sense of what philosophy can tell us. The point of the philosophical analysis of experience always concerns a living person's experience.

Husserl thus, on the one hand, can claim his phenomenological method to be the truly rigorous science, because-unlike natural science-it refuses to simply presuppose the life-world without making it a problem. On the other hand, it is probably not a coincidence that his pessimistic assessment of the abovementioned dream flows into the image of philosophy as a poetical re-invention of the history of philosophy (Husserl, 1970, 34 ff.). Here, he gets into the proximity of Collingwood's (Collingwood, 1970, $209 \mathrm{ff}$.) view of history as the only possible 'science of human nature,' which, however, Collingswood saw as throwing a questioning light on the very idea of the science of human nature.

Though Husserl's and Patočka's criticisms are not altogether easy to understand any more-being, in various details, connected to their contemporary science such 
as descriptive psychology - and at times may seem outdated, it is not impossible to understand the relevance of their point even in the most recent context. A target for a likely spirited phenomenological critique of today might be presented, for instance, in the evolutionary accounts of phenomena (institutions) such as culture, morality or religion. Although the evolutionary sciences can tell us a lot of interesting things about the probable origins of morality, etc. in our ancestors, it seems to be a misrepresentation of the role and the meaning morality has in our (social) lives if we argue that it has to be understood, say, as a 'sanctification' of the most profitable game-theoretical arrangements in a surviving community (or the like) ${ }^{5,6}$.

Similarly, Husserl's and Patočka's criticisms of science can be read as attempts at denying not the authority itself of scientific discoveries, but rather a particular interpretation made of these discoveries. We come to know things about our world not only in result of a scientific observation; and neither can-as Husserl came to see, in his disillusionment-an analysis of our knowledge of the world be provided in a rigorously scientific manner.

\section{CARNAP AND HUSSERL IN THE LABYRINTHS OF REDUCTION}

Much of Husserl's and Patočka's criticisms can be applied to the reductionist tendencies of logical positivism, although neither of them had this particular agenda in mind directly. They were generally aware of the activities of the Vienna Circle and were critical of the positivistic approach, but did not address them explicitly. They reflected more directly the works of the respected precursors of the Vienna Circle, such as Mach or Avenarius. Both of them responded in a more explicit manner even to Wittgenstein, who was also one of the role models of the heralded

5 Cf. the very different accounts of morality in Tomasello (2016), for whom morality is a sophistication of practical mechanisms of problem-solving and efficient cooperation in communities; and in Winch (1972, 172), who points out that morality is not a tool for solving independently existing problems, but rather opens up a sense of problems that one would otherwise not have at all.

6 I have mentioned Galileo as the source target of Husserl's criticisms in the opening of this section. The optimism about mathematics as the universal language does not characterise only the pioneers of early modern science, though. To an extent, it still accompanies the practice of natural science, as can be seen from the methodological enthusiasm inherent to Wigner's (1960) famous article. Wigner, with a clear insight, limits his focus to physics; but the question which sciences can be mathematised accordingly and to what extent remains open. On the one hand, we have game-theoretical (i.e., mathematical) models that aim at capturing the patterns of human behaviour in all important areas of human lives. On the other hand, there are (scientific!) voices pointing out that "science has contributed nothing to the answers [about the nature of Truth, Beauty, or Justice], nor does it seem [...] that science will do much in the near future," for "almost all of our experiences in this world do not fall under the domain of science or mathematics" (Hamming, 1980). 
revolution in science and philosophy. Husserl's Formal and Transcendental Logic contains a short appendix on tautology, in which Wittgenstein is referred to as a relevant logical authority (the author of the appendix was in fact Oskar Becker). Patočka knew Wittgenstein's Tractatus well and was perhaps its first perceptive reader in Czechoslovakia. In The Natural World, he presents a short critical reaction to Wittgenstein's conception of language. He identifies the strong points of Wittgenstein's logical atomism: taking facts and propositions with truth value for the foundational elements of his system, the transcendental role of language. But he sees its weaknesses, too: a narrow conception of language consisting of passively receptive pictures of facts, viz. underestimating the importance of human speakers' diverse transformative attitudes towards the world (Patočka, 1992, \$4.5).

Nevertheless, the scientism of the Vienna Circle, as expressed by its Manifesto, is itself an integral part of the broader tradition of Modernity. And, Modernity being one of the phenomenologists' principal targets, it is the naturalistic emphasis on distinguishing between primary and secondary layers of our experience ('qualities'), with its quantitative and empirical methods in epistemology, that attracts Husserl's criticisms.

Carnap is often considered the logical empiricist, with all the reductionist and foundationalist repercussions of empiricism. It is true that positivism got its clearest and most precise elaboration in his work. However, this perception of Carnap relies on the influential critical interpretation by Quine (1951) and Sellars (1997): according to them, for logical empiricists atomic perceptions (sense data) are the basic units of our knowledge of the world. Every other piece of knowledge is inferred from the statements of sense data.

The later generation of Carnap scholars-Friedman, Uebel, or Carus-criticises passionately this traditional interpretation. I don't want to insist here on the full appropriateness of the traditional Carnap interpretation. My point is rather to show that the critical reaction to positivism thus understood gave rise to some powerful philosophical insights.

The critical Quine-Sellars viewpoint fits, however,-though with some reservations-Carnap's Aufbau. The book is reductionist in its spirit. Nevertheless, Carnap discusses various options of the mutual reducibility between physical and psychological objects ${ }^{7}$. What we encounter as things are reducible to psychological

Uebel (2014, 45 ff.) shows that Carnap (in the Aufbau) pursued mutual translatability between the two kinds of statements. 
objects, such as perceptions, but even sense data can further be analysed, again, to the level of physical objects, and described in terms of our brain processes. The structure of the world involves such a "basis" and the ways of reduction to it and ascension from it (Carnap, 2005, \$59).

However, Carnap doesn't propose a metaphysics. His ambition was rather to provide a "rational reconstruction of our knowledge"-first of all, of knowledge provided by science (Uebel, 2011). Our perception is instantaneous; it doesn't literally build 'higher-level' objects out of the more basic ones, as a heap consists of grains. On the other hand, the rational reconstruction abstracts from the experiential unity to see, through logical analysis, what is directly perceived and where the apperceptive synthesis enters. The analysis of these logical complexes is needed for the sake of reconstruction of our knowledge in clearer and more transparent terms (Carnap, 2005, $\$ \$ 4,100$ ). The choice of physical objects as the explanatory basis was, presumably, led by the regularity of processes in the domain of the physical. Knowledge reconstructed in these terms can be expressed in a language with sufficient intersubjectivity, that is, in physicalistic language (Uebel, 2011, 779).

With language, however, the picture gets more complicated. A few years after the publication of the Aufbau, Carnap addressed the role of language from different angles. His proposal of 'physicalistic' language follows the Aufbau: Carnap prefers the language of empirical observation in which space and time coordinates represent locations of physical quantities (such as heat). Everyday language expressions can be translated to physicalistic language expressions ('hot' as ' $40^{\circ} \mathrm{C}$,' for instance), but not all of them. Those that cannot be translated cannot have a place in the system of knowledge rationally reconstructed (Carnap, 1931a, $441 \mathrm{ff}$.). As the units captured by protocol sentences, Carnap identifies (quantifiable) reports by scientific observers. Some of his other shorter texts, however, shift the emphasis towards empirical observations of sense data: atomic perceptions essentially describable by a system of coordinates (Carnap, 1931b; 1932).

Later on, Carnap himself abandoned the (epistemological) project coined in the $A u f b a u^{8}$ in favour of more holistic considerations in the philosophy of

8 His 1961 preface to the second edition (Carnap, 2005, viii) reflects on the book as a failed attempt to assert reducibility statements about things ultimately to statements about sense-data. As Uebel $(2011,777)$ shows this may be legitimately considered as a self-misinterpretation on Carnap's part, and rather difficult to explain. On the other hand, Abraham Stone stresses the continuity of Carnap's work, pointing out that even his later works continue to "to impose a roughly verificationist condition on the so-called observation language" (Stone, 2005, 129). 
science. Some ideas of the Aufbau show, however, to what extent Husserl's and Patočka's criticism might apply to Carnap. Perhaps most striking is the case of Carnap's remarkable account of "cultural objects." They "belong to other object spheres," and to insert a cultural object along with a physical object within a single assertion leads to a confusion. They can, however, through complicated analyses of the relationships of "manifestation" and "documentation," be made accessible as, ultimately, psychological or physical objects, respectively. Carnap's (somewhat puzzling) list of cultural objects contains "individual incidents and large-scale occurrences, sociological groups, institutions, movements in all areas of culture, and also properties and relations of such processes and entities" (Carnap, 2005, $\$ \$ 23 \mathrm{ff}$.).

Carnap's aim is not to state directly that our knowledge of cultural objects consists in the knowledge of their physical documentations or psychological manifestations. But their rational reconstruction means that an adequate analysis of knowledge dealing with these objects can best be described through defining the terms of this knowledge by means of a logical analysis reducing them in terms of physical objects. Carnap is here at odds with most of the consensus in the post-war social sciences, according to which the meaning of social and cultural phenomena cannot be explained by this kind of reductionist analysis, but rather depends on appreciating their contextual engagement in the lives of the particular societies, especially the bearing of the employed ideas for those who think these ideas (Winch, 1990, esp. the Preface to the second edition, or section V).

Yet, he does not displace culture to the margin of philosophical interest. His long-term collaboration with Bauhaus (see details in (Galison, 1990)) shows his concern for the organisation of the environment for human life. Bauhaus architects and theorists shared the positivists' attention to elements and constructions (resulting from mutual influence): reorganising the material world (mass housing projects, for instance) would lead to a reorganisation of human life. It is thus of utmost importance to reorganise it with a scientific focus on detail, function, and construction, clearing it of nationalist or historicising features (Galison, 1990, 711, 718). Knowledge of cultural contents, therefore, not only allows, but needs to be susceptible to rational reconstruction, for it is in reorganising the social life that the stakes are particularly high.

On the other hand, such pieces of our knowledge of the world that incorporate culture-related elements (and are not purged of historicisms) can resist the physicalistic analysis more tenaciously. Let us imagine one such 'unsuitable' example: "his life took a downward turn" doubtless can be seen as a piece of knowledge. It tells 
something about the world (it does relate to a place and a time), for it makes sense to ask whether it is true or false. When the statement "his life took a downward turn" is uttered even to a complete stranger, she will be able to understand it as a reflection or report on the situation of the person in question. Though she may not get all the particulars, the overall sense of the direction to which the statement points is not obscure to her. She would be able to characterise the sense in which this statement differs in what it amounts to from a statement such as "he could look back at his life with the feeling of satisfaction."

However, from Carnap's point of view, in order for this statement to be understood as a meaningful statement of knowledge, the analysis of the referred culturally-loaded contents ("a downward turn of a life") would have to be provided in terms of their rational reconstruction in terms of psychological and, ultimately, physical objects (manifestations and documentations). Let us not forget that even possibilities of a life better or worse are considered sensitive to the arrangements and (re-)organisations of the material world. Thanks to the laws governing these relationships can the statement be analysed and confirmed by a scientific observer.

How can we proceed when analysing the "downward turn"? Apart from being culturally-loaded, the expressions also mean something specific in varieties relative to different cultures. A reasonable answer to "how can you know such a thing?" might look very different from a reductionist analysis referring to documentations and manifestations intersubjectively agreed upon by scientific observers. It could take the shape of an interconnected story, such as The Mayor of Casterbridge. Its clarity doesn't increase with increasing density of "documentations" and "manifestations" of the downward turn or with extracting only the episodes of such manifestations and documentations from the story, leaving the insufficiently information-rich episodes aside.

But, on the other hand, if the rational reconstruction, allowing for a verification, succeeds, then knowledge reconstructed in these terms would amount to what it, truly and ultimately, means to know that "his [Michael Henchard's, for instance] life took a downward turn." Stating this knowledge in the form of simply saying "his life took a downward turn" or in the form of a story would then not be false, but compared to the reconstruction, insufficiently rationally organised. This result is not easy to accept, and not only for the phenomenologists.

Husserl's system is sometimes called foundationalist, just as empiricists and positivists (including Carnap) are often interpreted to be (Moran, 2000, 146; or more directly concerning Carnap: Mayer, 1991). In the case of them both, it is less 
than self-evident. The attribution of foundationalism to Carnap has been the target of extensive criticism; however, Husserl and Carnap shared an interest in mapping the relationship between things-objects of knowledge and the smaller elements of perception that feature in the analysis of this knowledge. For Husserl, our experience and understanding of the world always, primitively, takes the shape of (meaningful) things. Perceptual aspects of things-experiences can (sometimes) be isolated and pointed out, but the experience in no sense 'consists' of them. A thing is more than a sum of its demonstrable perceptual constituents (e.g. its different spatial perspectives) would be. While Carnap would not question the phenomenologically primitive nature of meaningful things, he still argues that it is on principle possible to "state [all] the indicators" of a thing explicitly, which is what only allows one to justify one’s intuition of a thing as knowledge (Carnap, 2005, \$100; Stone, 2005) 9 .

Unlike Husserl, Carnap would thus probably suggest that the "downward turn" of a person's life, and the tragedy of its course, however immediately it strikes the observer, is not known by her directly, even when she cannot present any logical connection to an intersubjectively verifiable, exhaustive set of indicators. Problems connected to this can best be bypassed, I believe, by making the notion of verification used more elastic and complex. (I will return to this in the next section with Wittgenstein.)

While Carnap retains a methodological openness towards reductionism (even exercises reductionist tendencies), Husserl's distrust of the foundational nature of sense data is straightforward. It shares certain features with the two vocal critics of logical positivism and empiricism, Quine and Sellars. A philosopher can explore various aspects of the "things themselves" only as secondary with respect to things, as things essentially are something that mean something. What one faces is not a bundle of sense data comprising a chair, but a chair first and foremost. Yes, one never encounters things directly in their full, possible entirety. Although I encounter a chair outright, and although I know it has another, unseen side, and I also typically know that there are further levels of what a chair may mean arising against horizons beyond the present setting, this is not something I directly see. What I see is rather that there is something more about this already fully meaningful thing, and I may

9 I am placing Husserl into a contrast to Carnap for the purpose of elucidating the differences in their approaches to foundationalism. However, there is a distortion resulting from the equivocation of 'reduction' in this context. While Carnap was genuinely interested in the question of reduction to sense data, for Husserl, the nature of 'reduction' is logical, or terminological: it allows us to see the formations of our experience cleared of the thesis of objective reality (Husserl, 1970, $\$ \$ 42-44$ ). 
yet come to see that. The sense (the fully meaningful experience) of things covers these various aspects, gradually contextualised into further horizons of sense. The ultimate horizon covering all the successive horizons is the whole world-the phenomenological world, the background against which things show themselves as meaningful ${ }^{10}$.

Husserl suggests that the flow of sense data is neither foundational nor (in opposition to Carnap) meaningfully, or rationally, reducible to physical objects of another kind. A meaningful talk about sense data presupposes their constitution out of the stream of experience: to be able to find sense data within the world is a result of employing a complex structure of interpretive theses about the world. In fact, the very apparatus of sense data is a part of the 'general thesis' of there being an external, objective, material, independent world (where sense data fulfil the role of the messenger connecting us with the world). And that would be a part of a very specific way of talking about things.

Although the gradual synthesis of the sense of, say, a chair can be followed backwards, through analysis, to the expurgated isolated aspects of the chair, these are neither elements of its sense nor do they provide its origin. The synthesis is the origination of sense, according to Husserl. The phenomenological elements of experience, expurgated of their horizons, mean only little to us. It is the synthesised sense, embedded into the constitutive horizons, that is the only true sense, neither secondary, nor composed, nor derived. The bodily nature of world-knowledge is one of these horizons; a chair means something qua chair within the world inhabited by bodily beings equipped for sitting (using and creating things suitable to sit on).

It is worth noting that Carnap's work from the 1920s reacts quite strongly to the work of Husserl that exercised a significant influence on it. Young Carnap attended Husserl's lectures for few semesters, although some archaeology is required to find out more about this connection, since Carnap himself disowns this part of his academic experience in his autobiography (Mayer, 1991). It is probably this Husserlian influence that resulted in certain remarkable features of the young Carnap's philosophical projects, e.g. his emphasis on "methodological solipsism." Their strong shared interest in discussing options of reduction also led some interpreters to see similar elements in Husserl's and Carnap's somewhat problematic solutions to the issue of intersubjectivity. For the two, intersubjectivity remained something to be

${ }_{10}$ Husserl $(1970, \$ \$ 28,48)$. The idea of the human life-world (Lebenswelt) as the horizon of meaningful things nevertheless pervades much of Husserl's work, especially in its later stages. 
constituted from simpler, more basic elements of experience by means of conjecturing other people's inner lives ${ }^{11}$.

The powerful pathos of Husserl's or Patočka's criticisms of philosophy too science-driven could not, I believe, be motivated by a real appreciation of positivist philosophy. At least Carnap's position is much subtler, more complicated and less straightforward than to justify these criticisms itself. They apply more appropriately to what a positivistic scientism can happen, and happens, in the hands of, say, science popularisers attempting to explain away things like justice, morality or religion as phenomena sui generis, having a place in our lives in their own right. I thus believe that the most apposite reading of their replies to the positivist scientism is not as of simple misinterpretations (though misinterpretations they are, to an extent). Much rather, they express a concern for the exploration of the place of the important facts and institutions in our lives. The hasty and unjust reading of positivist view thus shows, first and foremost, the importance that phenomenologists perceive in those facts and that they desperately want to not lose from their sight. This motivation is not exclusive to phenomenologists. Within the analytical tradition it finds its characteristic expression in Wittgenstein, rather than in Quine and Sellars.

\section{WITTGENSTEIN: VERIFICATION AND UNDERSTANDING}

As I have pointed out, Husserl and Carnap share a certain preoccupation with the reduction and analysis of our knowledge of the world and the separation of its constitutive elements. Though they disagree as to the nature of the ascension from the elements (logical complex vs. synthesis), they may share certain problems, namely, how to deal with non-trivial evaluative statements such as "his life took a downward turn" (not to mention the notorious troubles with other minds). Husserl's trouble is not as painful as that of some of the logical empiricists (if not Carnap himself) here; he is not obliged to advocate for a rationally reconstructing rephrase of such a statement providing empirical underpinnings of its meaning. However, the observation of another's life's downward turn is sometimes difficult to make. Such observations are connected to a certain adult understanding of other people's lives that one has to grow into (and that many fail to).

11 This is discussed in detail by Rosado Haddock (2008). 
In other words, if you want to understand what it is that you know when you know that "his life took a downward turn," it is far from obvious that a reductionist analysis of the concepts used in this statement of knowledge (objects referred to) is the best or the only way to take. If someone reacted to the request to clarify or explain her statement of another's life's degradation in this way, it could testify to the speaker's misunderstanding of what it means that someone's life took a downward turn.

A possible solution to these troubles is suggested by the early and 'middle' Wittgenstein's conceptions of logical atomism and verification. Wittgenstein's association with the Vienna positivists was only loose and complicated and his conversance with phenomenology problematic at best, but his reflections touch the very heart of the question whether (or how) there can be a science of knowledge.

The early Wittgenstein does not exemplify what an atomic fact or an elementary proposition looks like. He does not postulate the construction of an ideal language. Logical atomism may thus be 'logical' in the sense that the elements of the true cognition/experience of the world are represented by the simplest meaningful propositions of the natural, everyday language that speak about the world and can be true or false. The 'simplicity' refers to the impossibility of identifying propositions that would be understood as both meaningful (i.e. true/false) in their own right and comprising the analysed propositions (i.e. even simpler than these are ${ }^{12}$.

To be honest, in the Tractarian framework, it seems rather clear that what Wittgenstein envisaged as the way logical products originate consisted of the combinations of elementary propositions made by logical operators (conjunction, etc.) (Wittgenstein, 1961, 5). While it is not clear whether statements such as "his life took a downward turn" qualify as statements of facts in the Tractarian sense. If a statement of value, it would speak of something that is not quite "of this world"13. Yet, it talks about something that took place in this world. But even if it is not a value statement, but a factual one, it is not clear how to demonstrate whether or in what sense it is an elementary proposition or a logical product.

There is evidence in favour of the logical-product view, for we can talk about the sense constituents of this statement. For instance, "he succumbed to gambling"

12 Wittgenstein (1961, e.g. 3.3 and subordinate remarks). For a discussion of the unclear nature of Wittgenstein's elementary propositions that cannot be simply identified with sense-data observations or similar, see, for example, Anscombe $(1965, \$ 1)$.

13 Such is a possible interpretation of some of the final remarks in the Tractatus (Wittgenstein, 1961, 6.41 and connected remarks). 
is one of the things that could be stated in reply to the question of how one can know that "his life took a downward turn." Some would even admit that it offers a reasonable answer to the question of what the downward turn can consist of. Would that make "his life took a downward turn" a complex proposition? Evidently not in the same sense as "his life took a downward turn and he killed himself" is a complex proposition, of which one elementary constituent is "he killed himself." The relationship between "his life took a downward turn" and "he succumbed to gambling" is a different one. The meaning of the latter can be understood as a contribution to the meaning of the former, but we don't find this understanding through a formal analysis focusing solely on the proposition "his life took a downward turn." Whether and to what extent this proposition has to do with gambling has to be established by focusing on further practice of its use.

Here, Wittgenstein's reflections on verification enter. Wittgenstein's ideas from the Tractatus significantly influenced the Circle's debates on verification ${ }^{14}$. But the 'middle' Wittgenstein's own position mainly reacts to suggestions by his Vienna Circle friends Waismann, Schlick and Carnap, who started theorising about verification before him. (This is probably the reason why Wittgenstein says more about verification in the dialogues of Wittgenstein and the Vienna Circle than in his 'sole-authored' works from the same time such as Philosophical Remarks.)

From the very beginning, it seems clear that Wittgenstein is not interested in analysing what science does, or how scientific knowledge works. Much as this is a legitimate and honourable philosophical enterprise, an exclusive focus on science can obstruct the sense of importance (even primacy) of knowledge in the contexts where no science is concerned. For Wittgenstein, verification is thus not necessarily a (reductive) scientific confirmation. Rather, it is whatever meaningful, intersubjectively understandable procedure that allows us to tell whether a proposition is true or not, revealing thereby what it means and that one understands properly what it means (Waismann, 1967, 47). Verification in this sense is a constitutive part of the everyday language, and only derivatively of the scientific language (as a particular subspecies). Referring, in the process of investigating "his life took a downward turn," to "he succumbed to gambling" seems a reasonable way of verifying the former proposition. The question of which proposition consists of which and in what sense

14 In the Tractatus, a meaningful proposition involves a prescription or instruction: to understand its sense means to know what the fall is if it is true (4.024). I thus fix its sense by determining under what circumstances (Umstände) I can call it a true proposition (4.064). 
falls out of play here; gambling is a reasonable thing to mention when the discussion is open as to whether "his life took a downward turn" is true. This report also plays a significant role in elucidating the sense of the initial proposition and/or how the speaker understands it.

Verification of a proposition means to perform an operation required to deem it true, typically to perform further linguistic steps. Although the further statements make, in a sense, the initial statement true, this is not the case by virtue of their form alone. The connection between two such propositions may have nothing to do with their structural or formal features (remember the downward turn of a life and gambling). Rather, we show by engaging in this course of the verification practice that within our lives such pairs or groups of statements play such a role that, when we talk about the contents of our lives, we may come to understand naturally the latter as substantiating, in a certain way, the former. The sense of "his life took a downward turn" is therefore not synthesised from the sense of "he succumbed to gambling" and some further constituents. The former need not be understood as more complexly constructed than the latter. Yet, it seems to require a more complex understanding on our part to see what "his life took a downward turn" means, as something substantiated, for example, by "he succumbed to gambling," than to see just what "he succumbed to gambling" means. The very relationship between the two statements appears before our eyes when we use the latter to make sense of the former. This is a possible course of elucidation rather than the foundational analysis: these two statements may quite well not stand in this relationship or they can stand in analogous relationship to other, very different statements. (And yet, in some cases, if there was no gambling there would clearly be no life-degradation.) Whether and at what point they can be thus connected results from the courses of our lives and practices $^{15}$. The claim of verification is thereby not lost; as long as it makes sense to speak of the distinction true/false in the case of propositions such as "his life took a downward turn," it must make sense to speak of their verification as well.

\footnotetext{
15 In a slightly cryptic remark, Wittgenstein stresses the importance of talking about one's world, the primary reason being not that otherwise what one says could not be verified, but that it could not make any sense at all (Wittgenstein, 1964, 71). At this point, Wittgenstein is expressing a certain distance from the identification of meaningfulness with the availability of verification. A possible explanation is that verification typically enters explicitly the stage when the truth status of a proposition is explicitly discussed, i.e. under quite specific circumstances. On the other hand: what makes language meaningful is the speakers' engagement with the world they live in. This interpretation, however, relies quite heavily on the later Wittgenstein's reflections on the entanglement of language games with forms of life (cf. Wittgenstein, 2009, \$19). Locating such an anticipatory link in a text from the early 1930s might be too much of a stretch.
} 
Verification thus enters the stage even when the sense of a proposition is in some respect problematic. Sometimes (seemingly) one and the same proposition allows for many quite different courses of verification, which correspond directly to the different things it can mean, depending on the context (Waismann, 1967, 97 ff.). If there is ambiguity in what to do with a proposition in the course of verifying it, it corresponds to the ambiguity of its sense.

One of the examples Wittgenstein himself uses- "Seitz has been elected mayor [of Vienna]"- shows how difficult verification can be. It offers multiple options of verification cours $\mathrm{e}^{16}$, but none of them is essentially privileged and more than one may be practically equal. It also shows that knowing what to do with (especially) such a statement is inherent to the functional practice of engaged everyday speakers, rather than being a skill of scientific observers foremost.

The diversity of verification practices anticipates the later Wittgenstein's shift to the diversity of language use (Wittgenstein, 2009, \$353). There are, however, some substantial differences. The 'middle' Wittgenstein seems to omit the vast region of linguistic utterances, in the case of which it makes no sense (or only a significantly altered sense) to speak of truth/falsity (such as jokes or fictional stories). Yet these are meaningful; and the problem they represent does not consist only in there being separate sentential forms, such as commands or questions ${ }^{17}$.

On the other hand, although the middle Wittgenstein's notion of verification is rather embryonic and unelaborated (with residua of the original scientism), its emphasis on the role of truth (not only scientific truth) provides a feature distinctive from the later works. It allows us to see the dimension of the importance that statements have to the speakers. That the things we say to each other can be true or false, and that it is mostly preferable that they are true, is connected to the reasons why mutual intelligibility matters to us ${ }^{18}$.

Wittgenstein's notion of verification reconciles, in a way, Carnap's position with that of Husserl. It retains both 1) Carnap's intuition that, in order to tell whether

16 (Waismann, 1967, 48); cf. also (Wittgenstein, 1964, 87), on the diversity of verification procedures.

17 The differences in the sense of statements, questions and commands that are "about the same thing" might lie in their different relations to the Fregean "Annahme" shared by them. See Wittgenstein (2000, 145; cf. also MS 110, 94 in the Nachlass). The way one works with questions and commands shows that they have a sense that the speaker can know or fail to know, but she, obviously, doesn't show this by displaying her knowledge of a verification procedure, but probably rather by displaying a sense of the different ways in which commands and questions are related to the verification procedures of the statements that are "about the same thing."

18 This reading of the middle-later Wittgenstein relationship follows the criticisms of the later Wittgenstein's view on language, made by his pupil Rush Rhees (1959). 
a proposition is true and what it means, non-trivial recurrence to further propositions sometimes has to be performed, revealing sometimes unexpected relevant contents contributing to the sense of the former statement, and 2) Husserl's distrust of the need to search for anything more foundational behind the everyday (language, experience), using the tools of science and claiming the everyday to be secondary. Verification is, however, in its essence neither the movement of analysis (reduction) nor reverse-engineered synthesis, but the movement of elucidation.

Wittgenstein's increasing lack of interest in a 'de-composing' analysis as the privileged tool makes his notion of verification akin to hermeneutical circle. Verification is a movement of understanding what one knows; and as the hermeneutical circle (a circle of understanding) has no beginning, structurally simpler moments of understanding can substantiate just as well as be substantiated by structurally more complex moments ${ }^{19}$.

Understanding what "his life took a downward turn" means presupposes a preliminary familiarity with contexts where certain typical (explanatory) cases of life-degradation occur, and also the initial acceptance that one's life (one's existence) is something that matters just as much as its eventual ruination. This means understanding how such a statement could be expanded upon-what other options are likely opened or precluded for 'him' by the downward turn. These further illuminating connections are not essentially hierarchical in the sense that we would thus identify the necessary constitution elements of this piece of knowledge. More naturally, the network spreads horizontally; seeing the connections means getting the person's (degraded) life in a clear sight.

Understanding this statement or issuing it (being able to issue it) does not require that it be composed of pieces such as "he succumbed to gambling" or even of localised sense-data observations. The viewpoint needed to see the ruined life may be reached via "he succumbed to gambling," but also quite well without it. The sense of "his life took a downward turn" does not literally consist of such pieces as "he succumbed to gambling" even if the person actually did so. The relationship is different. We make these and analogous connections in the course of our human interactions and dealings with others; to help the others (or ourselves) understand. ("Now I know what you mean. Now I see why you say that his life took a downward turn."). Verification-despite taking sometimes the scientific shape-is located

19 More about the parallels between Wittgensteinian analyses and Heidegger's hermeneutical proposals see in Gier $(1981, \$ 10)$. 
within, and proves to be an important dimension of, the relationship network of interpersonal intelligibility. The 'here and now' context of the actual making oneself intelligible cannot be explained away, including who speaks to whom, or what one is capable of make out of the intimation, etc.

Wittgenstein's expanded notion of verification, emancipated from the positivistic scientism (thanks, probably, to Waismann's influence), thus offers an option of expanding the concept of knowledge. Yes, we can know even such things as "His life took a downward turn." What we offer as further pieces of knowledge, thanks to which we state our knowledge of the former pieces,- - such as "Well, he succumbed to gambling and threw his family into poverty"-does not result from a scientific analysis. There are no connections of the kind that a scientific procedure discloses; one needs to (learn to) see these internal connections of what one knows.

\section{THE CASE OF SOUL}

The example of the downward turn of a life is not Wittgenstein's own. (In his discussions of verification, the farthest away that he moved from the positivists' example imagination was with "Seitz has been elected the mayor.") I have not chosen, however, an example of this sort randomly. It is telling that while it can be accommodated by Wittgenstein's concept of verification without significant problems, its positivistic analyses leave, at least, a sense of certain awkwardness.

Within the confines of a narrow reading of Tractatus, the example "his life took a downward turn" may be dismissed as a statement of value. "Downward turn" is a second-step evaluation of a factual event or situation, one might say. Even if that is the case, that is not to say that statements of value cannot be known, as opposed to the fundamentally knowable statements of fact. Some optimism is at place also because the turns that our lives take are not from "outside this world," they take place in a particular place and time. ("That was before he went to Paris where his life...”). The statements of these turns speak about things that happen. What makes it seemingly problematic is the fact that they deal with the course of people's lives in terms that introduce concepts like 'the meaning (of life),' 'good,' or 'soul.' For the downward turn is not a description of a mountain slope, or of a person's failing health (or aging), or (at least not necessarily) of the worsening material conditions of one's life. The closest concept at hand, if one wants to avoid the all-encompassing talk of 'life,' would be that of soul and what happens to it. 
Carnap is often understood as banishing disdainfully all talk about God or soul outside meaningful language; for him, statements talking about soul are not statements of facts - of what is happening here and now-, but expressions of life feeling (Carnap, 1931a, section 7). In reality, his public lectures for Bauhaus shew that he was fully aware of the high importance of the matters of life feeling (Dahms, $2004,168 \mathrm{ff}$.). If he classifies 'soul' as a 'pseudoproblem of philosophy', it is because he repudiates any metaphysics of a substance called 'soul,' which survives the death of the body etc. Unfortunately, only if soul is one kind of object or another, can matters of soul be subject to knowledge or verification. Expressions of life feeling cannot; and this trouble Carnap sought to avoid.

Wittgenstein, especially in his later philosophy, evades this dilemma. Even though soul is not a 'thing,' it is present in what is happening here and now with and to a person. "His life took a downward turn" can also be rephrased in terms of a corruption or degradation of the person's soul. Without obliging ourselves to any afterlife metaphysics, we can know what happens to a person's soul here and now, exactly insofar as we can know what happens to a person, to her life. We cannot, however, know this as scientists, because this is knowledge of facts only in a very special sense, if at all. It is in this direction that Wittgenstein's later reflections on human body being the best picture of human soul point (Wittgenstein, 2009, II, \$25). What happens to a person's body can be seen and what happens to her soul can be seen, too. But the latter can also be overlooked in ways that, unlike the cases of failing to see the former, may have nothing to do with the lack of physical visibility (Wittgenstein, 1984, I, \$1106). The insight has, partly, to do with employing judgment (Wittgenstein, 2009, II, \$355) and, I believe, good will, too.

These analyses are close to Husserl's analyses of the "psychic (seelische) reality." His conception of body as Leib parallels Wittgenstein's "picture of human soul": soul does not stand besides or hide behind body: body can only be Leib as the (bodily) presence of a soul in this world (Husserl, 2000, \$21, or Supplement XII.II, \$1). As Husserl says, it is not that one first observes a body and then conjectures about the soul; a human being—and an attitude towards a human being as such —is a unity: “...grasping a corporeal existence $[. .$.$] is not the attitude I am in when I see a man.$ I see the man, and in seeing him I also see his Body." (Husserl, 2000, 251f) And "[e]mpathy into persons is nothing else than precisely that apprehension which understands the sense." (Husserl, 2000, $255 \mathrm{ff}$.).

Husserl, though, mostly discusses the general structure of encountering any Other as a human being. The problem of understanding or failing to understand 
the particularities of the course of an individual life, which haunted Wittgenstein, is left aside. (Mis)understanding the course of another's life (what happens to his soul) moves along an extremely wide continuum. In cases where "His life took a downward turn" represents its more insightful end, the blind end, reached via the complacent "He's just fooling around," would be something like "Oh he's such a drama queen." All these are, however, various forms of "attitudes towards a soul"; and all would differ extremely in kind from attitudes adopted towards a soulless thing ${ }^{20}$.

Somewhat analogously, Husserl speaks of man as a unity of body and soul. This unity is manifested through the adopted 'personal attitude,' one that differs radically from any kind of causal or dualistic conception and would be lost by an attempt at introducing the latter kind of attitude (Husserl, 2000, 192, 247). Not surprisingly, any understanding of another takes shape of 'understanding of their motivations.' It is thus, again, in these, and not other, terms that any misunderstanding proceeds. 'Oh he's such a drama queen' is nothing else than empathising the other's motivation, however misguided or deluded this 'empathy' may prove.

I may be pushing Husserl too far into the territory of epistemology. That encountering another person amounts, always, to encountering a soul is rather a matter of the primitive sense-constitution of the situation as such (a primordial given). In other words, that I meet soul-endowed beings is not a piece of knowledge that I may or may not acquire ${ }^{21}$. It is much the same as what Wittgenstein would call a "grammatical statement." With understanding what is going on in or happening to a particular soul, things seem more complicated, though. I indicated above that "Oh he's such a drama queen" was a form of empathising another, rather than of coming to get a piece of knowledge. Husserl truly proceeds in such a direction: the "relations of mutual understanding" are a higher and a more specific level of empathising others as souls "full stop." They result in yet another level of the sense-constitution of the surrounding world (Umwelt); though this constitution stems from the source of mutual (intersubjective) interactions of recognition or struggle ${ }^{22}$. Not incidentally, the resulting structure still represents an object for a science; though one has to make very clear that it is not natural science. Trying to apply the lens of natural science here would mean to stay "blind to the spiritual sphere, the special domain of the

20 More about the variety inherent to the Wittgensteinian notion "attitude towards a soul" see in Phillips (1992).

21 More about the difference between the sense-constitution and epistemology in the context of Husserl's explorations of soul see in Cobb-Stevens (1983).

22 Cobb-Stevens $(1983,252)$ calls this aspect of Husserl's analysis of sociality "Hegelian." 
human sciences” (Husserl, 2000, \$51). (Ideas II, though a work of Husserl’s mature period, still precede by some ten years the disillusionment about the possibility of science, expressed in the Crisis.)

Wittgenstein harbours no ambition to make insights of the kind of "his life took a downward turn" a matter of a systemic sense-constitution, following any kind of laws that a science could study. He, too, would not apply any procedure of verification to the hypothesis (?) that others are people, that they have soul. If one can plausibly (and not only as an expression of an armchair Cartesian scepticism) claim this, she must be lacking such an amount of conceptual resources that the room for a verification talk would be drastically limited. The presence of soul, demonstrated in our attitudes, is not a matter of knowledge. We do not discuss it or ask questions like "What makes you say so?" or say things like "Remarkable! I didn't know that" (of "I didn't realise this until you opened my eyes"). But we do when it comes to "his life took a downward turn."

This is because in the latter kind of cases, we do not have to do with a ground on which we would all 'always already' stand. One's capacity to be an insightful and empathizing companion to a particular other is not the matter of the senseconstitution of a layer of intersubjective 'psychic reality.' To the extent that this is true, there is no science dealing with the knowledge of the turns that others' lives take $^{23}$. In the sense of an analysis of the conceptual differences between attitudes towards souls as such and insights into the lives of particular souls, Wittgenstein, however, never lost an interest in "a descriptive phenomenology of forms of life, i.e. the formal structures which make a meaningful life possible” (Gier, 1981, 32).

\section{TO CONCLUDE}

Husserl's Prague lectures and Patočka's first book present indirect but very pertinent objections to the logical empiricism and positivism of the members of the Vienna Circle. Much of these critiques is still alive, though they concern a more vulgar, vague idea of scientism or scientific understanding of the world than the

${ }^{23}$ Glendinning $(1998,140 \mathrm{ff}$.$) argues that dealing with others as souls takes shape of reading (in a Derridean$ sense). While his focus is on the issues such as scepticism or criteria of other minds, or the difference between first and third person, his interpretation can be extrapolated for our purposes, too. Reading, though, is also an art that one has to acquire with time. Much as it feels spontaneous, automatic, there is always room for missing the sense of the 'text.' Experience, wisdom, or patience - rather than the application of a scientific method-can diminish this risk. 
actual work of their contemporary positivists, along with its complex development. They show powerfully that not only is the world we live in and understand not the world science claims to discover, along with its foundational building blocks. It also seems almost a strange kind of hubris to claim that so long as our lived experience of the world differs incompatibly from what science says about the world, it has to be understood as derivative or even misleading or delusional. When, however, our experience, as we phrase it, is misleading, trying to understand it better may mean strikingly different things than just applying the lens of rational reconstruction to it. Failing to understand that someone's life took a downward turn, and why is that, would be one such case.

Carnap and many of his generation fellows sincerely believed that there should, and could, be such a thing as the science of human knowledge. Husserl and Patočka believed in the possibility and desirability of a rigorous philosophical account of human knowledge and wished-which is, I think, the proper expression-that this account could be made scientific. (At least Husserl, as I said, faltered in his faith towards the end of his philosophical career.) What makes Wittgenstein distinct from both is his firm conviction that there could be no such thing as a science of human knowledge. Philosophy explores and elucidates the pathways on which living, engaged, situated human beings struggle to understand the world as they know it. Projects of rephrasing knowledge of the world in terms of a science can compromise philosophy's sense of understanding what it is that we know as a task inherent to each and every person's life.

This overall ethos brings, however, Wittgenstein to the proximity of phenomenology, I believe. What makes him relatively unique among the analytical philosophers of his generation is that he tried to tackle what he considered as shortcomings in the views of Carnap \& Co. (in many respects misattributed, no doubt) in a way that betrayed the kind of motivations that would come more commonly or more naturally to a phenomenologist. Both for Wittgenstein and for his contemporary phenomenologists, what is at stake is understanding of one's life in the world from within what the life is like for the one who lives it. For this purpose, soul and all that concerns soul must be taken into account not in an eccentric, marginal position, but as a matter of knowledge and understanding that pervades, foundationally, each context in which the talk of knowing and understanding makes sense. 


\section{REFERENCES}

Anscombe, G. E. M. (1965). An Introduction to Wittgenstein's Tractatus. New York: Harper and Row.

Carnap, R. (1931a). Die physikalische Sprache als Universalsprache der Wissenschaften. Erkenntnis, 2, 432-465.

Carnap, R. (1931b). Überwindung der Metaphysik durch logische Analyse der Sprache. Erkenntnis, 2, 219-241.

Carnap, R. (1932). Über Protokollsätze. Erkenntnis, 3, 2150-228.

Carnap, R. (2005). The Logical Structure of the World. Chicago: Open Court.

Cobb-Stevens, R. (1983). Body, Spirit and Ego in Husserl's 'Ideas II'. In A.-T. Tyminiecka (Ed.), Soul and Body in Husserlian Phenomenology (243-258). Dordrecht: Reidel.

Collingwood, R. G. (1970). The Idea of History. Oxford: Oxford University Press.

Dahms, H.-J. (2004). Neue Sachlichkeit in the Architecture and Philosophy of the 1920's. In S. Awodey \& C. Klein (Eds.), Carnap Brought Home (357-375). Chicago: Open Court Publishing.

Galison, P. (1990). Aufbau/Bauhaus: Logical Positivism and Architectural Modernism. Critical Inquiry, 16, 709-752.

Gier, N. F. (1981). Wittgenstein and Phenomenology. Albany: SUNY Press.

Glendinning, S. (1998). On Being with Others. Heidegger - Derrida - Wittgenstein. London: Routledge.

Hamming, R.W. (1980). The Unreasonable Effectiveness of Mathematics. The American Mathematical Monthly, 87, 81-90.

Husserl, E. (1970). The Crisis of European Sciences and Transcendental Phenomenology.Evanston: Northwestern University Press.

Husserl, E. (2000). Ideas Pertaining to a Pure Phenomenology and to a Phenomenological Philosophy II. Kluwer: Dordrecht.

Mayer, V. (1991). Die Konstruktion der Erfahrungswelt in Carnap und Husserl. Erkenntnis, 35, 287-303.

Moran, D. (2000). Husserl and the Crisis of European Sciences. In M. W. F. Wolff \& J. Stone (Eds.), The Proper Ambition of Science (122-150). London: Routledge.

Moural, J. (2013). Czechoslovakia. In L. Embree (Ed.), Encyclopedia of Phenomenology (123-129). Dordrecht: Springer.

Patočka, J. (1992). Přirozený svět jako filosofický problem [The Natural World as a Philosophical Problem]. Praha: Československý spisovatel. (in Czech).

Patočka, J. (1995). Tělo, společenství, jazyk, svět [Body, Community, Language, World]. Praha: OIKOYMENH. (in Czech).

Phillips, D. Z. (1992). My Neighbour and My Neighbours. In D. Z. Phillips, Interventions in Ethics (229 -250). Basingstoke: Macmillan.

Quine, W. V. O. (1951). Two Dogmas of Empiricism. The Philosophical Review, 60, 20-43.

Rhees, R. (1959). Wittgenstein's Builders. Proceedings of the Aristotelian Society, 60, 171-186.

Rosado Haddock, G. E. (2008). The Young Carnap's Unknown Master: Husserl's Influence on ,Der Raum' and ,Der Logische Aufbau Der Welt'. Aldershot: Ashgate.

Sellars, W. (1997). Empiricism and the Philosophy of Mind. Cambridge, MA: Harvard University Press.

Stone, A. (2005). The Continental Origins of Verificationism. Angelaki: Journal of the Theoretical Humanities, 10, 129-143. 
Stone, A. (2010). On the Sources and Implications of Carnap's ,Der Raum'. Studies in History and Philosophy of Science, 41, 65-74.

Tomasello, M. (2016). A Natural History of Human Morality. Cambridge, MA: Harvard University Press.

Uebel, T. (2011). Rudolf Carnap. In S. Bernecker \& D. Pritchard (Eds.), The Routledge Companion to Epistemology (774-785). London: Routledge.

Uebel, T. (2014). Carnap's 'Aufbau' and Physicalism: What Does the 'Mutual Reducibility' of Psychological and Physical Objects Amount to? In M. C. Galavotti, E. Nemeth, \& F. Stadler (Eds.), European Philosophy of Science - Philosophy of Science in Europe and the Viennese Heritage (45-56). Wien: Springer.

Waismann, F. (Ed.). (1967). Wittgenstein und der Wiener Kreis. Oxford: Basil Blackwell.

Wigner, E. (1960). The Unreasonable Effectiveness of Mathematics in the Natural Sciences. Communications in Pure and Applied Mathematics, 13, 1-14.

Winch, P. (1972). Moral Integrity. In P. Winch, Ethics and Action (171-192). London: Routledge \& Kegan Paul.

Winch, P. (1990). The Idea of Social Science and its Relation to Philosophy (2nd ed.). London: Routledge.

Wittgenstein, L. (1961). Tractatus logico-philosophicus. London: Routledge.

Wittgenstein, L. (1964). Philosophische Bemerkungen. Frankfurt: Suhrkamp.

Wittgenstein, L. (1984). Bemerkungen über die Philosophie der Psychologie. Frankfurt: Suhrkamp.

Wittgenstein, L. (2000). The Big Typescript. Wien: Springer.

Wittgenstein, L. (2009). Philosophische Untersuchungen (4th ed.). Oxford: Wiley. 